Jelena Osmanović Zajić

ORCID: 0000-0002-2289-9438

Jelena Maksimović

ORCID: 0000-0001-8356-0211

Gordana Petrović

ORCID: 0000-0001-8819-1603

University of Niš, Serbia

Faculty of Philosophy

\title{
The significance of John Amos Comenius' great ideas for the development of pedagogical research ${ }^{1}$
}

DOI: $10.34739 /$ szk.2021.08.12

\begin{abstract}
This paper presents the pedagogical significance of John Amos Comenius and how his pedagogical ideas influenced the development of pedagogical research. By analyzing Comenius' ideas, we have shown their connection with the development of pedagogical research. Mankind still does not find more original ideas than his, but returns to his opus and finds more and more new knowledge in it, which builds on the existing educational theory and practice. The aim of this paper is to identify which of Comenius' pedagogical ideas contributed to the development of pedagogical research and thus the Methodology of Pedagogy as a scientific discipline. Primarily, we want to place Comenius' philosophical and pedagogical views in the context of their importance for the development of pedagogical research. The tasks are formulated as follows: 1. Analysis of the pedagogical significance of John Amos Comenius, 2. Analysis of the historical development of pedagogical research in Serbia. 3. Pointing out the connection between the principles founded by John Amos Comenius and the development of pedagogical research. The method of theoretical and historical analysis with the technique of content analysis of historical and pedagogical sources and documents was used. After presenting Comenius' pedagogical ideas, the paper presents the development of pedagogical research in Serbia and the principles of Comenius in which we found the basis for the development of pedagogical research.
\end{abstract}

Keywords: John Amos Comenius, pedagogical research, methodology of pedagogy, principles, history of pedagogy

\section{Introduction}

John Amos Comenius (1592-1670), a Czech philosopher, pedagogue, linguist and politician, is considered the founder of modern pedagogy. His

\footnotetext{
1 This paper is the result of research done within the project: "Development and perspectives of the Department of Pedagogy of the Faculty of Philosophy in Nis", no. 100/1-10-5-01, funded by the Faculty of Philosophy, University in Nis, Serbia.
} 
works contributed to him being considered one of the most important reformers in pedagogy, because he devised an educational system that significantly changed the understanding of the connection between a child's development and his education. The education of John Amos Comenius began at the age of sixteen when he entered the Latin school in Prerovo. The very fact that he started school late speaks in favor of why he advocated the importance of education from an early age and was committed to the development of the educational system. His philosophy is called pansophism, and through it, through his works, he wanted to reduce the entire notion of the organization of the world and the universe to simple, comprehensible notions and relations, which in detail indicate the whole world (Spevak, 2020). Characteristic of his entire pedagogical work is that he basically created a new ideology, which did not imply the improvement of the already existing one. His ideas represent a pedagogical revolution in previous knowledge and it can be freely said that there is still a basis for discovering the beginnings of many sciences and scientific disciplines that later developed from the philosophical understandings he set. The significance of his work is reflected in the existence of a special discipline of comeniology, which is named after him (Maksimović et al., 2020). Comenius left great ideas in his works that should be studied and their connection with the theory and practice of education of today should be discovered. The author Maksimović and her collaborators have been studying the significance of John Amos Comenius for the last few years, by studying the connection between his learning and the origin and development of the methodology of pedagogy and pedagogical research techniques and instruments (Maksimović and Sretić, 2019; Maksimović and Osmanović, 2017). Precisely these works served as an idea to investigate the connection between Comenius' ideas and the emergence of pedagogical research and to start from the assumption that the foundations of pedagogical research are found in Comenius' opus, that is, from the principles that arose from his ideas.After presenting the pedagogical significance of Comenius, we will show how the development of pedagogical research in Serbia went and the contribution that this Moravian thinker left to the development of pedagogical research and methodology of pedagogy as one of the most important pedagogical disciplines.

\section{Pedagogical significance of John Amos Comenius}

In order to point out the pedagogical significance of Comenius, it is necessary to start from his entire ideological understanding of the world, pansophism, which forms the backbone of all his achievements that are applicable in educational theory and practice. He is considered the founder of didac- 
tics because he weaved his philosophy into the definition of this scientific discipline: "the skill of teaching everyone everything" (Komenski, 1967: 14). His greatest discovery is the frontal form of teaching, on the occasion of which he said "that he is happy to have found a method by which a small number of teachers will be able to work with a large number of students and more successfully with hundreds than with one student" (Ibid.). John Amos Comenius wrote over 150 works, while works such as Great Didactics, Informatory for the Mother's School, Sensual World in Pictures, Open Doors to Languages, experienced 250 editions each (Arsić and Banđur, 2019). Comenius looked at science from a practical point of view, that students learn what will benefit them in life (Cenić and Petrović, 2005). His pedagogical significance is also reflected in the fact that he defined the school year, week, day and class. He pointed out the need to change work and rest, as well as to define the class. He recommends the same time for going to school, in the fall, as well as grading at the end of the school year. From this we see how modern his pedagogical ideas were, even in his time, and how unsurpassed they have remained to this day.

Comenius relied on the ideas of antiquity, humanism and the Renaissance, as well as on Quintilian's views from the book "On the Education of Speakers", from which his demands to treat children gently, non-violently and without criminal proceedings (Spevak, 2020). On the request to adapt education to nature, as the most general principle of Comenius, his pedagogy is based (Žlebnik, 1970). This principle represents the starting point of Comenius' pedagogical ideas, and his ideas are derived from it, which have contributed to the establishment of scientific disciplines in the domain of educational work with children. Presenting his views on upbringing, he overcame the medieval onesided approaches to man, with his pansophic wisdom, complete understanding of the world and synthesis of scientific, philosophical, ethical and religious achievements (Mihajlović and Janjić, 2020). The four essential elements on which Comenius' pansophism is based are the universal book, the universal school, the universal college and the universal language (Maksimović et al., 2018). Through the division of the educational age into four periods of six years of life, he tried to implement his favorite idea of pansophism (Cenić and Petrović, 2012), not knowing that in that way he would lay the foundations of a modern school system. Education should take place gradually, in phases, from easier to harder, following human nature, which is adapted to the natural need to acquire knowledge. To make this achievable, Comenius proposed the following educational possibilities which he explained in his work The Great Didactics: 1. Education for all, 2. Learning as a natural tendency of man, 3. Learning in stages, 4. Financial support, 5. Preparation for life, 6. Extracurricular activities and 7. Lifelong learning (Krulj et al., 2020). 
The importance of Comenius for the entire educational system knows no bounds, with the increasing number of researches and analysis of his works, the number of facts that speak in favor of the importance of his pedagogical work is increasing. The most important merits of Comenius that increase his pedagogical importance relate to the democratization of education, which becomes available to a wider social strata, the introduction of order in educational content by differentiating them into subjects, the introduction of class-hour system, the introduction of frontal teaching establishing a system in which the school year and class schedule are defined (Vilotijević, 2009). In the continuation of the paper, we will try to point out his importance for the development of pedagogical research, i.e. which of his ideas have contributed to the knowledge of the importance of pedagogical research, without which innovations of educational work in the future are not possible.

\section{Historical development of pedagogical research in Serbia}

Motives that lead to organizing and conducting pedagogical research can be the result of scientific interest - the effort of science to study a particular problem in order to develop as successfully as possible, practical needs the result requires scientifically based answers to certain questions and problems and personal interest - the researcher's desire to study and investigate an issue and problem and discover new truths (Banđur and Potkonjak, 1999). In order for a certain science to develop, it is necessary for it to continuously research and come up with scientific laws. The goal of pedagogical research is theoretical and practical. Theoretically, it implies the discovery, determination, formulation and communication of known pedagogical laws, while in practice it represents the determination of the possibility of application (practical use) of discovered laws in educational activities (Ibid.).

In order to understand how the development of pedagogical research in Serbia went, we must first start with the development of pedagogy as an academic discipline. Researching the literature, we can say that the beginnings of the development of pedagogy as an academic discipline are related to the development of the teaching profession. With the creation of the Professor's Society in 1889, the introduction of a permanent pedagogical department at the Faculty of Philosophy began (Bakić, 2009). After that, in 1892, the Department of Pedagogy was created, $\mathrm{PhD}$ was appointed professor (Vujisić Živković, 2012) and in 1894, on the birthday of John Amos Comenius, the Pedagogical Seminar was founded (Bakić, 2009). Along with the development of pedagogy as an academic discipline, the development of pedagogical research took place, which can be seen as early as 1897, when Bakić published General Pedagogy, which emphasized the research importance of pedagogical 
science (Vujisić Živković and Spasenović, 2020). We see the next step in the development of pedagogical research in Serbia in the penetration of experimental pedagogy through translated and domestic articles and monographs on the methodology of scientific, experimental and descriptive work in pedagogy (Ibid.).The main representative of the experimental direction in Serbian pedagogy was Paja Radosavljević, a professor at the Faculty of Pedagogy in New York. Scientific-research work after the Second World War is beginning to be increasingly appreciated, which can be seen in the progress of the empirical methodological orientation in the approach to educational problems since the 1950s (Ibid.). This progress resulted in the establishment of the Institute for Pedagogical Research in 1959 - the year in which they begin to translate the most important works of methodology, organize seminars in pedagogical statistics, publish the first manuals in the field and empirically oriented research, which is the beginning of the constitution of the empirical methodology of pedagogical research in Serbia (Gutvajn et al., 2014).

The author Nikola Potkonjak (Potkonjak, 1994) divides the process of development of pedagogical science in the post-war period into 5 periods: (1) The first development period-time from the liberation of the country to the First Congress of Pedagogues of Yugoslavia (1944 / 5-1952); (2) The second developmental period - the period of searching for the authentic epistemological-methodological basis of Yugoslavia socialist pedagogy (1952 / 3-1963); (3) The third development period - the constitution of Yugoslavia socialist pedagogy (1963-1970); (4) The fourth development period - the period of self-governing pedagogy (1970-1986 / 7); (5) The fifth development period the period of searching for a new identity of pedagogy (1986 / 7-1991 / 2). Guided by this periodization, the authors Maskimović and Petrović (Maksimović and Petrović, 2012) presented in their work how the development of the methodology of pedagogy and thus pedagogical research in Serbia went. The first development period (1944 / 5-1952) is characterized by the underdevelopment of pedagogical research, because in this period there were no research pedagogical institutions, staff, or appropriate methodology, and therefore pedagogical problems were not scientifically studied (Potkonjak, 1994). In this period, we can single out the most important appointment of Nikola Potkonjak in 1951 as an assistant for the subject of General Pedagogy at the Faculty of Philosophy in Belgrade, which will significantly contribute to the development of pedagogy and methodology of pedagogy (Maksimović and Petrović, 2012). The second development period (1952 / 3-1963) marks the beginning of the methodological reorientation and in this period, as we have already stated, the first and only Institute for Pedagogical Research was opened. In the following period of development of pedagogical science, which la- 
sted from 1963 till1970, the aim was to clearly define pedagogy (Potkonjak, 1994). This period is also characterized by the introduction of courses in Methodology of Pedagogy in the study of pedagogy. The study subject Methodology of Pedagogical Research with Statistics began to be taught in 1962 at the Faculty of Philosophy in Belgrade, while the first complete textbook on the methodology of pedagogy with pedagogical statistics was published by Vladimir Mužić in 1968 (Maksimović and Petrović, 2012). For the next two developmental periods, which covered the period from 1970 to 1992, we can single out efforts to find case studies and ethnographic research, the impact of information technology on the methodology of pedagogy (Banđur and Potkonjak, 1999).

In the last decade of the 20th century, we can say that the development of pedagogical research flourished. This is supported by the appearance of numerous journals and professional papers in the field of pedagogical research methodology. Some of the publications that marked this period are: Innovations in school as a subject of research (1992), On research, method and knowledge (1995), Pedagogical research in school (1996), Fundamentals of pedagogical research methodology (1997), Methodology of pedagogy (1999), Lexicon of Pedagogical Methodology (1999). In the 21st century, the trend of development of pedagogical research has continued, where the qualitative and quantitative paradigm in the research of social phenomena is reconciling (Maksimović, 2011). Action research is emerging, as a novelty in the improvement of educational practice, which enables the solution of specific problems that teachers encounter in their practice, i.e. the improvement of practice. Grozdanka Gojkov, Veljko Banđur and Milenko Kundacina contributed to its development in Serbia. We have created personnel, material, institutional and scientific bases that are a guarantee for the development of pedagogy methodology in Serbia (Maksimović and Petrović, 2012).

If we take into account the overall development of pedagogical research and the methodology of pedagogy as a scientific discipline, we can see that the path of their development was long and difficult. When the importance of their application for educational practice was recognized, there was a rapid development and aspiration for the obtained knowledge to be scientifically based. Man's very desire to know is woven into his nature, contributes to the development of civilization and leads to new achievements from different fields of work. It is inevitable that the further development of pedagogical research will proceed faster and faster, because of an increasing number of experts for whom the research of pedagogy and education has become a part of their professional obligation. In the continuation of the paper, we will try to find the bases for the development of pedagogical research in the principles of John Amos Comenius, studying the relevant literature. 


\section{Principles of John Amon Comenius as a basis for the development of pedagogical research}

The significance of John Amos Comenius for the development of pedagogy is enormous and boundless. His influence on the development of pedagogical disciplines has not yet been sufficiently researched. The authors Maksimović and Sretić (Maksimović and Sretić, 2019) point out that Comenius made a revolution in the understanding of upbringing and education with his ideas, laying the foundations for their research. If we look at Comenius from today's angle of scientific knowledge of the methodology of pedagogy, we would see him as a practitioner. Given his efforts and commitment to improve school practice, even then we can notice the beginning of the idea of pedagogical research. His understandings of the importance of pedagogical experience have a high theoretical reach, as well as great practical significance (Banđur and Potkonjak, 1999). We see what Comenius did for the educational system in the 17th century as a result of his long research into existing practices that resulted in scientific discovery. However, many at the time did not recognize the importance of the knowledge he gained or their practical application in schools. Comenius, on the basis of the experiences he gained while working in the school and the fact that the number of students in the then public schools was increasing, created a new and original system of science (Ibid.). With his contribution to the development of pedagogy as a science, John Amos Comenius laid the foundations on which pedagogical disciplines developed later. In order to innovate the schools, he first had to research the existing educational practice and see the shortcomings that existed. This method may not have satisfied today's interpretation of pedagogical research at the scientific level, but it was a form of research. The scientific discoveries he made were not acceptable in the time in which he lived, but their significance was later recognized and represents one of the greatest contributions to educational practice.

The specificity of pedagogical research is reflected in the way of gaining new knowledge in pedagogy and in the fact that "scientific truths and scientific discoveries in pedagogy, no matter how objectively based, are different in nature from those in the natural sciences" (Banđur and Potkonjak, 1999: 91). He was often condemned for his attitudes and beliefs expressed in his works, but he was adorned with the pedagogical passion with which he acted in the theory and practice of education (Maviglia, 2016; Glenn, 2018). Studying the literature, we learn that in addition to the mother school, mother tongue school, Latin language school and academy, he also planned a school for scientists in which scientists would work with the task of improving all 
schools, on the basis of which we can consider him the originator of the institute Kachapor, 2003).

Author Stobrin (Sztobryn, 2020), who researched pansophism through the works of contemporary Polish scientists, points out that this philosophy of Comenius has undergone a historical evolution and has numerous consequences that are close to modern trends in scientific research and due to its complexity is presented as a synonym for encyclopedism. There is a new pedagogical trend in the 17 th a century, later known as realism, which implies a new way of considering education, school and learning, as well as a new understanding of the concepts of man and life, through a scientific explanation of reality (Maviglia, 2016). The author Maviglia (2016) also points out that Comenius' modernity became clear through his understanding of universal peace and the necessary cooperation among people in all spheres of life, in order to create an honest human society and improve the conditions of humanity, especially through educational practice (Maviglia, 2016: 58). If we look at the change in educational practice from a modern angle, it is clear that for this we need the results of a series of pedagogical research that proves the need to change practice, and we see the forerunner of this idea in Comenius' philosophy.

Comenius' pansophism represents the idea of a synthesis of human action that should lead to self-knowledge (Sitarska, 2020: 241). On the basis of developed critical thinking and the need to change the ugly reality in which he lived, his pedagogical ideas, guidelines for constituting a new sciencepedagogy, arose. The author Norlin (2020) claims that the Great Didactics is a gold mine because it represents the basis for understanding how different pedagogical areas and ideas were formed, and points out that we can always return to his works with new analytical perspectives. Although many decades after his death he seemed lost and forgotten in time, there was a resurgence of scientific interest in his ideas and methods, when at the end of the 19th century several scientists began to study his works (Glenn, 2018). Comenius devoted his entire life to the search for the improvement of the teaching process and education, his success can be seen in the fact that his didactic principles are still standing the test of time (Krulj et al., 2020). By analyzing the literature, we can single out certain principles that are the basis of almost all classifications and which are still relevant from Comenius to the present day, with small modifications. These are: the principle of gradualness and systematicity, adaptation and obviousness (Tomčić, 2020, see Dubljanin, 2010). Analyzing the pedagogical work of Comenius from the angle of methodology of pedagogy, Maksimović and associates (2018) pointed out three didactic principles that form the backbone of this scientific discipline: the principle of conscious activity, the principle of fundamental acquisition of knowledge and 
the principle of connecting theory and practice. We will try to connect these principles with the basics of the development of pedagogical research. The authors Maksimović and Sretić (Maksimović and Sretić, 2019) investigated the connection between the principle of obviousness and pedagogical research techniques and instruments and recognized that observation as a research technique is based on the principle of obviousness. In this way, the authors made a significant contribution to discovering the connection between the principles set by Comenius in the 17th century and the development of pedagogical research. The principle of gradualness and systematicity implies "that without the systematic acquisition of knowledge there are no scientific facts and generalizations, i.e. there is no scientific view of the world because every science has its systematicity" (Krulj et al., 2003: 205). The application of this principle is important for pedagogical research in terms of a good interpretation of the obtained research results, which should be presented gradually and systematically so as to form a logical whole. We know that one of the constitutive requirements that every science should meet is the scientific system of knowledge, which also indicates the importance of the principle of systematicity for research. On the other hand, the principle of conscious activity, which we find in Comenius' ideas, implies conscious and planned participation of students in the educational process with a clearly set goal of didactic activity and stimulation of research activities (Maksimović et al., 2018). The principle of connection between theory and practice is the basis of research methodology in education. The authors Maksimović and Osmanović (2017) dealt with the fact that although the tendency to connect theory and practice appeared much later in the methodology of pedagogy, Comenius is a forerunner of this principle because "all his works have a methodological and empirical character" (Maksimović and Osmanović, 2017: 334). When it comes to the principle of fundamental acquisition of knowledge, Maksimović et al. (2017) found a connection between thorough and gradual access to information and pedagogical research, which thus results in continuous feedback (Maksimović et al., 2017). They also point out that the practical application of the results and knowledge obtained is one of the most important elements of the methodology of pedagogy, as well as that the purpose and goal of every research work and learning is reflected in the possibilities of its use in practical situations (Ibid.).

At the end, we would like to emphasize the importance of Comenius' syncretic method for the development of pedagogical research. The author Woldring (2016) points out that Comenius' pansophism is characterized by metaphysics which includes a system of ideas and categories for understanding various phenomena and applying a syncretic method to discover impor- 
tant common components that will lead to the desired results. This author also points out that Comenius' syncretic method is the most suitable for formulating empirical research hypotheses, and pansophism can help overcome the one-sided rationalism of scientific research by showing the courage of presenting utopian ideas that are suitable for improving the world (Ibid.).

\section{Conclusion}

This paper is another attempt to show how important the pedagogical ideas of John Amos Comenius are for the educational process of today. The analysis of the used domestic and foreign literature led us to the conclusion that the principles set by Comenius in the 17th century were the basis for the development of pedagogical research. The roots of the development of pedagogical research are reflected in Comenius' ideas so they lead us to inexhaustible topics for pedagogical research that has been done so far and that will only be conducted in the future. The knowledge that Comenius gave us is the main foundation of pedagogical research and forms the basis for its further improvement.

Guided by the principles of Comenius, pedagogical research achieves its goal, which is to arrive at new scientific truths and enable their practical application. Today, there are various objections to the traditional teaching, which is mainly based on Comenius' pedagogical ideas. Work should be done to improve and eliminate such weaknesses precisely through the adequate application of the principles set by Comenius. His contribution to pedagogical science has yet to be researched and applied in the existing educational practice. In order to improve upbringing and education, pedagogical research is necessary. With this paper, we have shown how Comenius contributed to the development of pedagogical research. He was the first one to point out the need to open a school for those who will research and work on improving the school. From this data we can conclude that he attached importance to the research of pedagogical practice and its improvement.

The connection between the principles of systematicity and gradualness with pedagogical research is the scientific system of knowledge obtained by researching educational practice. The principle of obviousness is at the core of research methods and in this way we find its connection with pedagogical research. The principle of conscious activity implies research activity which leads to new knowledge. When we place the principles of the connection between theory and practice and the fundamental acquisition of knowledge in the framework of pedagogical research, we conclude that the results of any research are interpreted and applied with the help of these principles. 
The methodology of pedagogy as a young scientific discipline is yet to be improved and developed, as well as the pedagogical research that forms an integral part of it. In the following research, we can propose finding and examination of a connection between Comenius' syncretic method and the methodology of pedagogy. In this paper, we briefly touch on the connection between Comenius' syncretic method and pedagogical research, but it remains to be seen how important it was and can be for the methodology of pedagogy.

\section{Bibliography}

Arsić Zvezdan, Veljko Banđur, Развој дидактичког схватања. „Зборник радова Филозофског факултета у Приштини" 2019, 49 (2), s. 223-238.

Bakić Vojislav. Beleške o prosvetnim i kulturnim, političkim i ratnim događajima u Srbiji. Užice: SAO - Učiteljski fakultet, 2009.

Banđur Veljko, Potkonjak Nikola, Metodologija pedagogije, Beograd 1999.

Cenić Stojan, Petrović Jelena, Vaspitanje kroz istorijske epohe, Vranje 2005

Dubljanin Saša, Potreba za novom interpretacijom didaktičkih principa , „Pedagogija” 2010, 65(1), s. 169-172.

Glenn Justin, The intellectual/theological leadership of John Amos Comenius, „Perichoresis" 2018, no 16 (3), 45-61. DOI: 10.2478/perc-2018-0016.

Gutvajn Nikoleta, Đerić Ivana, Malinić Dušica, Pedeset pet godina Instituta za pedagoška istraživanja - 1959-2014, Beograd 2014.

Kačapor Sait, Sadržaji iz opšte istorije pedagogije, Pančevo 2003.

Komenski Jan Amos, Velika Didaktika, Beograd 1967.

Krulj Radenko, Kačapor Sait, Kulić Radivoje, Pedagogija, Beograd 2003.

Krulj Jelena, Vidosavljević Slađana, Mladenović Nataša, John Amos Comenius-the teacher of nations and the founder of didactic, „Zbornik radova Filozofskog fakulteta u Prištini" 2020, no 50(3), s. 101-121.

Maksimović Jelena, Pluralizam istraživačkih paradigmi u pedagogiji, „Pedagoška stvarnost" 2011, 57 (1- 2), s. 33-47.

Maksimović Jelena, Petrović Jelena, Razvoj metodologije pedagogije u Srba, „Istraživanja u pedagogiji" 2012, 56(34), s. 151-161.

Maksimović Jelena, Osmanović Jelena, Pedagoški rad Jana Amosa Komenskog sa osvrtom na princip povezanosti teorije i prakse u metodologiji pedagogije, In: B. Sitarska (red.), Współczesne recepcje Jana Amosa Komeńskiego, „Siedleckie Zeszyty Komeniologiczne, seria pedagogika" 2017, t. IV, s. 327-336.

Maksimović Jelena, Osmanović, Jelena, Milanović Aleksandra, Značaj Jana Amosa Komenskog za razvoj metodologije pedagogije, w: B. Sitarska (red.), Jan Amos Komeński w epoce współczesnošci, „Siedleckie Zeszyty Komeniologiczne, seria pedagogika" 2018, t. V, s. 105-119.

Maksimović Jelena, Sretić Sanja, Principle of evidence of John Amos Comenius as a basis for the development of pedagogical research tehniques and instruments, „Siedlce Comeniological Research Bulletin” 2019, no 6: 243-256. DOI: 10.5604/01.3001.0013.6255.

Maviglia Domenica, The Main Principles of Modern Pedagogy in 'Didactica Magna' of John Amos Comenius, „Creative Approaches to Research” 2016, 9 (1), s. 57. 
Mihajlović Tatjana, Slaviša Jenjić, Društveno - istorijski kontekst, naučni dometi $i$ aktuelnost školskog $i$ nastavnog procesa Jana Amosa Komenskog, „Педагошка стварност” 2019, 66, s. 19-33.

Norlin Björn, Comenius, moral and pious education, and the why, when and how of school discipline, „History of Education” 2020, 49(3), s. 287-312.

Potkonjak Nikola, Razvoj shvatanja o konstituitivnim komponentama pedagogije u Jugoslaviji (1944/45-1991/92), Institut za pedagogiju i andragogiju Filozofskog fakulteta, Beograd 1994.

Spevak Zoroslav, Ideja prirodnosti - temeljni princip didaktičkog sistema J. A. Komenskog, „Pedagoška stvarnost” 2020, 66, s. 9-18.

Sitarska Barbara, Pansophism as John Amos Comenius' idea of lifelong learning, w: B. Sitarska (red.), Pansofia Jana Amosa Komeńskiego w interpretacjach i reinterpretacjach polskich $i$ europejskich komeniologów, „Siedleckie Zeszyty Komeniologiczne, seria pedagogika" 2020, t. VII, s. 231-276.

Sztobryn Sławomir, In search of Comenius' pansophism in the research endevours of Polish scholars, B. Sitarska (red.), Pansofia Jana Amosa Komeńskiego w interpretacjach i reinterpretacjach polskich i europejskich komeniologów, „Siedleckie Zeszyty Komeniologiczne, seria pedagogika" 2020, t. VII, s. 37-50.

Tomčić Lana, Princip očiglednosti kroz delo Orbis sensualium pictus, „Педагошка стварност" 2020, 66, s. 44-58.

Vilotijević Mladen, Promenama do efikasnije škole budućnosti - nova paradigma za organizaciju buduće škole, „Zbornik radova sa naučnog skupa Buduća škola” 2009, 2, s. 713-750.

Vujisić Živković Nataša, Vojislav Bakić i razvoj pedagoške nauke u Srbiji, Beograd 2012.

Vujisić Živković Nataša, Spasenović Vera, The development of pedagogy as an academic discipline in Serbia-between scientific and vocational needs, „Razvoj i aktualne tendencije pedagogije i školstva na području nekadašnje Jugoslavije" 2020, s. 270-287.

Woldring Henk, Comenius' Syncritic Method of Pansophic Research between Utopia and Rationalism, „Gewalt sei ferne den Dingen” 2016, s. 23-43.

Žlebnik Leon, Opšta istorija školstva i pedagoških ideja, Beograd 1970. 